\title{
Toward a community resilience framework for disaster risk management. a case study: landslide Cisolok in Sukabumi 2018 and Sunda strait tsunami in Pandeglang 2018
}

\author{
Osmar Shalih ${ }^{1,2}$, Hafid Setiadi ${ }^{1}$, Triarko Nurlambang ${ }^{1,2}$, and Widyawati Sumadio ${ }^{1,2}$ \\ ${ }^{1}$ Department of Geography, University of Indonesia, 16424 Depok, Indonesia \\ ${ }^{2}$ Indonesian Disaster Expert Association (IABI), 16180 Bogor, Indonesia
}

\begin{abstract}
Along with the increase in large and medium-scale disasters in the world, including in Indonesia, in the last decade, many theories and practices have developed in terms of measuring and improving disaster resilience. This study discusses the conceptual model of community-level disaster resilience and disaster risk reduction. Using a basic conceptual model for spatial protection to geological hazard, research examines the role of community resilience in reducing risk by using social dimensions. To explore the conceptual model of spatial resilience at the community scale, case studies conducted in two disaster events, are (1) communities affected by landslides in Cisolok, Sukabumi District on 31 December, 2018 and (2) Sunda Strait tsunami in Pandeglang tourism area on 22 December, 2018. Research suggests that the importance of social capital in terms of forming community resilience is related to disaster risk reduction. Social network, social experience, social knowledge and belief systems, contribute to increasing resilience and disaster risk reduction. The results of this study are the importance of building social capital and spatial resilience of communities in reducing disaster risk.
\end{abstract}

\section{Introduction}

Geographically, Indonesia is in the active Pacific ring fire region. Indonesia is also located on three (3) large tectonic plates, namely the Indo-Australian, Eurasian and Pacific plates. Geographically, Indonesia is vulnerable to earthquakes, tsunamis, volcanic eruptions and other types of geological disasters [1-4]. Indonesia is one of the most vulnerable geological disasters in the world.

According to the National Disaster Management Authority in Indonesia (BNPB-RI) Data in 2018, it can be seen that, from more than 1,800 disaster events in the period 2005 to 2018 more than $78 \%(11,648)$ of the disasters were hydro-meteorological disasters and only around $22 \%(3,810)$ geological disasters. Although only $22 \%$, geological disasters have a major impact on humans, such as, in 2018, for example, based on BNPB data, the earthquake in West Nusa Tenggara in 2018, earthquake and tsunami in Central Sulawesi in 2018, the Sunda Strait tsunami in 2018 and landslide disasters in Sukabumi District in 2018. Trends in the threat of disasters from time to time in Indonesia continue to increase, but cannot be predicted accurately. In general, the Indonesian state is still not ready to face the incidence of large and medium-scale disasters. This is based on data and learning of the occurrence of large and medium-scale disasters in the last five (5) years [5]

Amid the uncertainty of the disaster which is difficult to predict and continues to increase, it is necessary to develop disaster resilience. Disaster resilience needs to be built on the smallest scale, namely in individuals and communities. This paper will discuss disaster resilience at the community scale in the context of disaster risk reduction management. Another interesting thing is that the Sunda Strait tsunami was not preceded by a largescale earthquake trigger (which was generally a tsunami caused by tectonic activity), but because of the volcanic activity of Mount Krakatau. Furthermore, for the 2018 Sukabumi landslides, geological factors were dominantly causing disaster risk, but the main trigger was rainfall (hydrometeorology factors).

\section{Methods}

This study uses a qualitative analytic approach. Qualitative research is considered to be able to examine social phenomena, namely community resilience to disasters, due to the nature of research that is profound, natural and produces or reconstructs new theories or knowledge.

The conceptual foundation used is interpretive geography. The data used include primary data, namely in-depth interviews, documentation and field observations (Fig. 1 and Fig. 2). Secondary data are textual data in the form of literature studies, scientific works, studies and research reports.

The focus of the research was carried out in the postlandslide location of Sukabumi 2018 in Cisolok and the Sunda Strait tsunami in the Coastal Tourism Area in

\footnotetext{
* Corresponding author: hafid.setiadi@ui.ac.id
} 
Pandeglang District. The unit of analysis used is a form of disaster resilience on a community scale, especially the social dimension. Reviewing spatial behavior is used in research to explain the relationship or relationship between phenomenon (spatial system) and the development or change of phenomenon (spatial process).

Research is not comparative, but rather describes two (2) phenomena of disasters, especially disaster with social perspective. Next is the research data triangulation. Triangulation is done to validate the study and is carried out on data sources, both primary and secondary data.

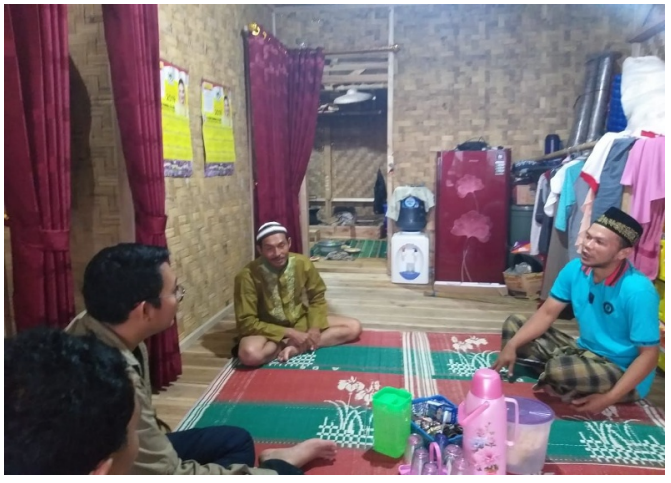

Fig. 1. I-depth interviews with Sukabumi landslide -affected communities

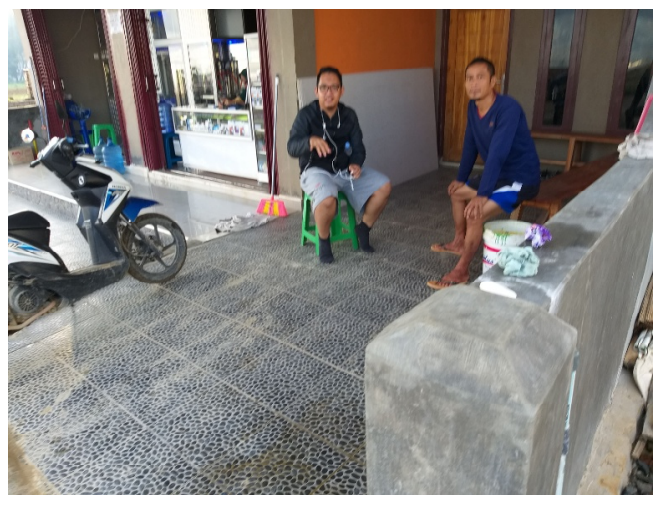

Fig. 2. In-depth interviews of the Sunda Strait tsunami in affected Pandeglang communities

\section{Results}

\subsection{Community resilience framework for disaster risk management}

The UN Office for Disaster Risk Reduction (UNISDR) states resilience is the capacity of a system, community or community that has the potential to be exposed to disasters to adapt, by surviving or changing in such a way as to achieve and maintain an acceptable level of function and structure. This is determined by the level of ability of the social system in organizing themselves in increasing their capacity to learn from past disasters, better protection in the future, and improved disaster risk reduction efforts [6].
Conceptually, community resilience includes three (3) aspects, namely: (1) community capacity to reduce risks or threats through mitigation and adaptation; (2) capacity to maintain basic functions and structures during disaster situations, and (3) capacity to recover from post-disaster events [7-9]. In the concept, it is stated that there are five (5) thematic fields that contain the characteristics of communities or communities that are disaster resilient, namely: (1) governance; (2) risk assessment; (3) knowledge and education; (4) risk management and vulnerability reduction; (5) disaster preparedness and response.

In the context of this research, many adopted the social dimension as a form of disaster resilience. Based on the literature, the social dimension is one of the factors forming community resilience to disasters.

From various literature, social capital plays an important role in shaping disaster resilience. Sadri et al. (2018) conducted a study on communities in Southern Indiana, USA in the face of tornadoes showing that social capital is very important in addition to physical infrastructure. Studies show that fast or slow recovery depends on social capital factors, personal networks and assistance from emergency responders on the overall recovery experience. From the study it was concluded:

Delayed recovery experience:

- The more the physical items destroyed, the longer the recovery experience

- Slower recovery experience if assistance received from private insurance companies

- Larger size of households can delay the recovery effort

Faster recovery experience:

- Households recover early if having higher level of trust in the government

- Households with denser personal networks experience quicker recovery

- Households with higher geographic proximity of network partners experience early recovery

- Households with assistance from neighbors experience faster recovery

- Faster recovery experience if having previous disaster experience

- Less time is required if longer time is spent in current home) [10].

Khalili et al. (2018) state there are 14 social resilience indicators, i.e.:

- community participation - the engagement of community members in organizations and activities within their community, including resident associations, neighborhood watches, self-help groups and religious congregations

- education - disaster-related formal and informal training and educational activities within communities

- exchange of information - information flow within a community

- learning - learning from previous disasters

- shared information - distributing information within a community

- $\quad$ social support - support from the neighborhood 
- sense of community - feeling of belonging to a community or place

- trust - trust in the neighborhood

- demographic information - i.e., age, gender, socioeconomic status/income, health, history, education, cultural/religious belief, or populations with special needs

- improvisation-inventiveness - community creativity and innovation to devise a solution for enhancing resilience

- coping style - the ability to manage, adapt to and deal with stressful situations

- leadership - leadership within a community [11].

\subsection{Community resilience: A Case Study Landslide Cisolok Sukabumi 2018}

The landslide disaster that occurred on 31 December, 2018, was not predicted beforehand and without an early warning system. Based on BNPB data, 33 people died. Landslide locations were in Garehong Village, Cimapag, Sinaresmi Village (Kasepuhan Sinaresmi), Cisolok District, Sukabumi Regency, West Java Province. Based on interviews, in addition to casualties, the landslides also caused damage to homes and residents' rice barns, communal toilets, clean water pipelines, agricultural land, and mosques (Fig. 3)

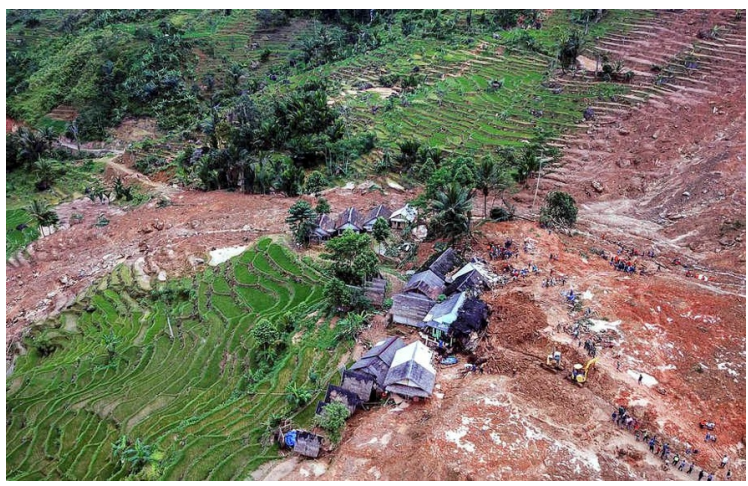

Fig. 3. The area affected by landslide (Garehong Village, Kasepuhan Sinaresmi, Cisolok, Sukabumi)

From the social dimension, the community has strong social capital. Adaptation has been done by moving from the place of origin, although it is still limited to the red zone (landslides hazard). This limitation of adaptation is due to sense of place or place attachment. This is due to the fact that the communites have been living down in the area and the area is also an indigenous area of Kasepuhan so that social networks are very strong. The government's efforts to exclude communities from the red zone will experience steep roads due to the attachment to living quarters. This also happens in other cases in the world; the concept of sense of place means the problem of relocation due to disasters always consists of two (2) sides, namely the reason for staying or migrating from a disaster-affected area $[12,14]$.

So, living in harmony with disaster needs to be done. Mitigation efforts need to be carried out, both structural and non-structural. Nature needs to be guarded, because the cause of landslides in the area is the conversion of land from the forest to agriculture (rice fields). Nonstructural mitigation efforts have been confirmed by the dissemination of information that forests are not private property and must be maintained. In local languages it is called 'leuweng titipan' or 'entrusted forest' (Fig. 4)

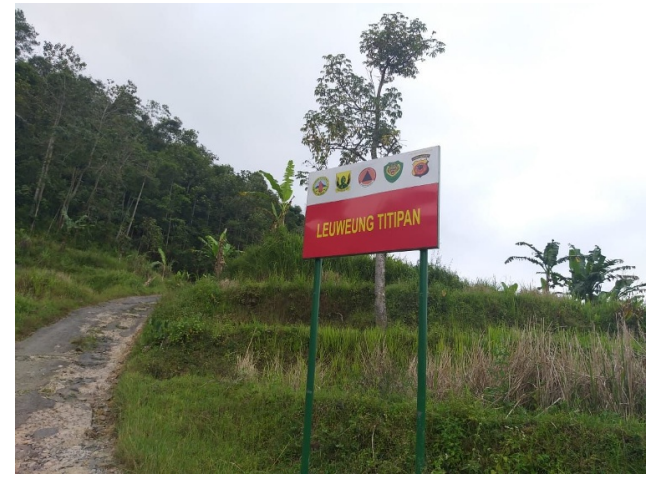

Fig. 4. Non-structural mitigation (information dissemination: sustainable forest)

During the emergency response period, social capital plays a very large role in the context of disaster resilience. Communities are very dependent on social networks. Basic needs in the form of ready-to-eat food and other basic needs are met by the help of various institutions. Assistance during emergency response is very abundant. During emergency response, social capital also plays a role in temporary shelter. Victims of disasters live in the homes of the closest relatives. The process of building a house is relatively fast. As of June 2019 , it is almost 100 percent built due to the strength of social networks (Fig. 5).

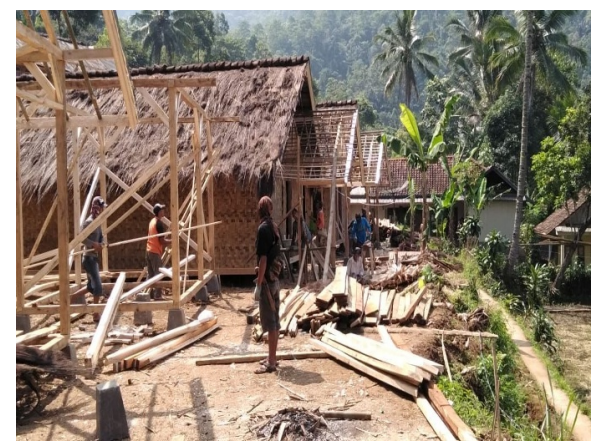

Fig. 5. The process of building houses for the relocation of affected communities

The community also has local wisdom in a landslide disaster. Some local wisdom, in local languages (Sundanese), are "bentengan", "ngalelemah", "ngabeberah" and "talutug". "Bentengan" is a local wisdom in the form of structural mitigation of landslide disaster. It is formed by rock and red soil without using cement. "Bentengan" is strong enough, because of the small plants and moss will be grow for a long time, so that will be strengthened the construction of "bentengan". Another advantage is the rock gap will function as an outlet for water entering from the top of the slope. This system would be maintain the stability of 
the slope because the water content in the slope have been balanced (Fig 6).

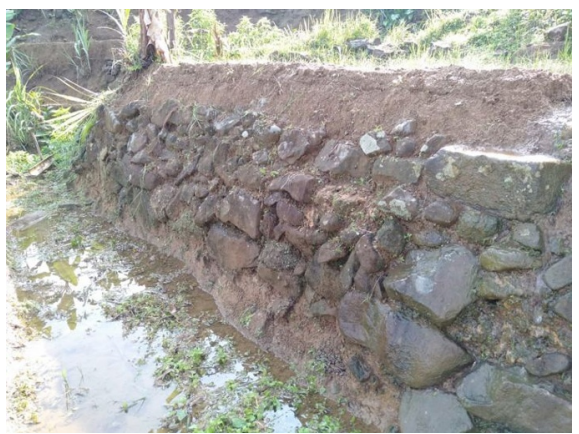

Fig. 6. "Bentengan" = Local Wisdom in Structural Mitigation of Landslides

"Ngalelemah" is a local wisdom in the form of land management by leveling the land because a building will be built on it. "Ngalelemah " is part of landslides mitigation because it cuts the slope length so that the load and force of sliding of slope will be reduced. Therefore, it will be maintain the stability of slope (Fig 7). "Ngebeberah" is a local wisdom in the form of efforts to repair rice fields were damaged by landslides. Landslide material will be left for 2 (two) years, then the land will be reprocessed to its form. This effort, according to the community perception, is important to maintain soil fertility (Fig 8). "Talutug" is local wisdom in the form of efforts to improve rice field are affected by landslides. The construction of rice fields will be strengthened by a fence of bamboo. Then, the material of rice fields were reassembled in its place (Fig 9).

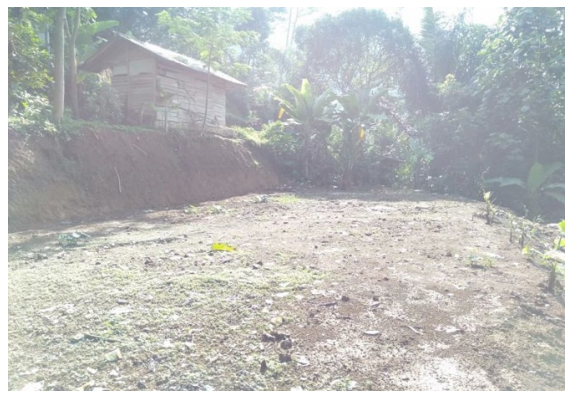

Fig. 7. "Ngalelemah $"=$ Local Wisdom in Structural Mitigation of Landslides

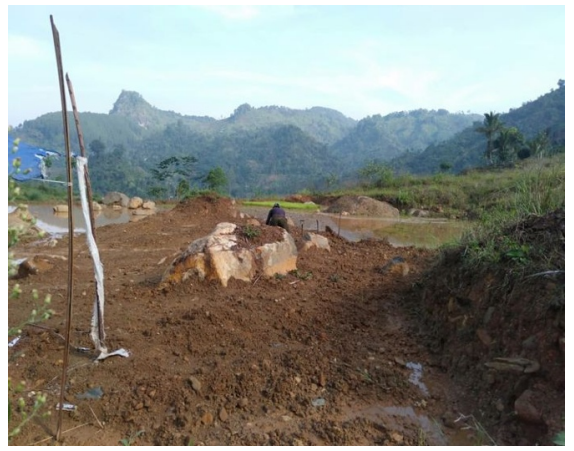

Fig. 8. "Ngebeberah" = Local Wisdom in Structural Mitigation of Landslides

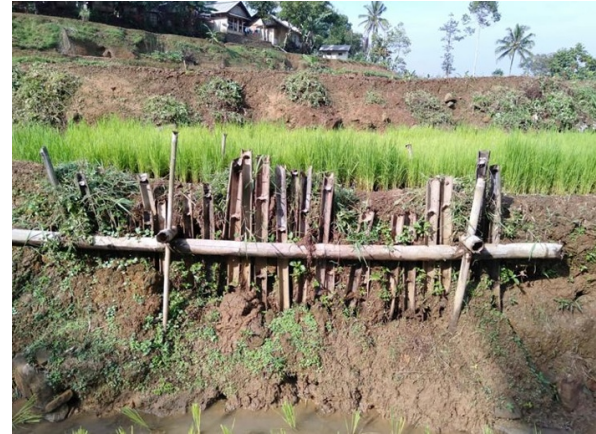

Fig. 9. "Talutug " = Local Wisdom in Structural Mitigation of Landslides

Knowledge of disasters is formed by the length of people's stay, place attachment and similarities of the characteristics of the area where he lived before [13]. Furthermore, the community still adhere to the local wisdom of hereditary. However, despite the advantages of community disaster resilience, the community still has difficulty bouncing back due to livelihood factors. They have not been able to return to activities that are generally farming. Their land is damaged, so until now (June 2019), their livelihoods have not recovered. At present, they depend on the remnants of assistance during the emergency response phase. Livelihoods are important in terms of building community resilience and their relation to social capital [14]. The community itself has not thought about ownership of disaster insurance or livelihood insurance (such as agricultural insurance and so on).

\subsection{Community resilience: A Case Study Sunda Strait Tsunami in Pandeglang 2018}

The Sunda strait tsunami on December 22, 2018, had an impact of 296 people died, three people were not found, 675 people were injured, 3,553 people were displaced, and damage caused to homes, public and social facilities and infrastructure ranging from severe, moderate and light. However, the worst affected sector is tourism. Tourism development, especially in the massive coastal areas in Pandeglang Regency without accompanying tsunami disaster mitigation, led the sector to experience the most severe impact during the December 2018 Sunda Strait tsunami. The damage and losses amounted to Rp. 16,425,350,000 (damage) and Rp. 63,669,600,000 (loss). Total damage and losses reached Rp. 80,094,950,000. Tourism was the worst affected sector compared to other development sectors. After the Sunda Strait tsunami occurred on December 22, 2018, the coastal tourism sector in Pandeglang District was paralyzed. In areas along the west coast of Pandeglang, the majority of tourists who were on vacation in lodgings around Carita Beach and Tanjung Lesung were victims. The tsunami also caused damage to hotel buildings, villas, resorts, huts, homestays, inns and other tourism objects [15].

In the context of disaster resilience, affected communities have made adaptation and mitigation efforts. The form of adaptation is to stay in the place of 
origin (sense of place) or (place attachment / job attachment) even though the house is affected by the tsunami. The community/continues to live (does not want to move house / relocate) due to attachment to the place of residence, namely livelihood factors that depend on the location of residence (fishermen, stalls or shops near beach attractions, villas / cottages near the beach, etc.) while the form of mitigation is done by planting trees (structural mitigation forms). Non-structural mitigation is carried out in the Tanjung Lesung area by installing an early warning system. Some points in the Sumur region install warning signs in non-structural mitigation contexts (Fig. 10).

Factors of social capital also play a role in the context of displaced affected communities in the aftermath of a disaster. Affected communities live in relatives' homes or evacuate during emergencies until recovery. After the emergency response period is complete, during the recovery period (June 2019) practical government assistance is very minimal.

The severity of the impact of the tsunami has an effect on speed, in addition to access and capital capacity of community ownership (Fig. 11). The government's role is minimal after a disaster, such as housing and capital assistance, and business access is also closely related to the speed and capacity of community recovery. With government assistance and community recovery capacity gets better and bouncing back on the impact of disasters can be an opportunity to become a bounce forward (build back better).

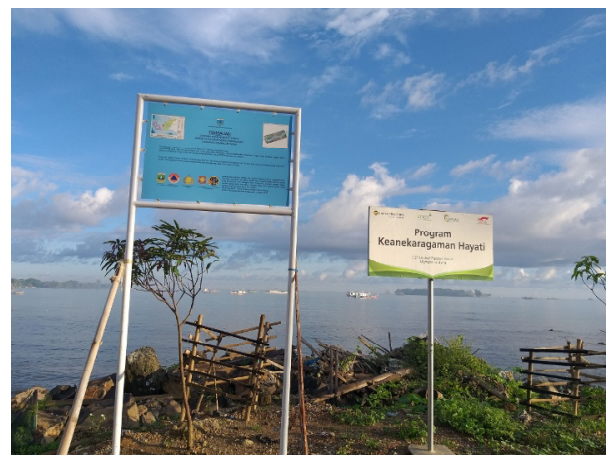

Fig. 10. Non-structural mitigation (information dissemination: tsunami hazard or red zone)

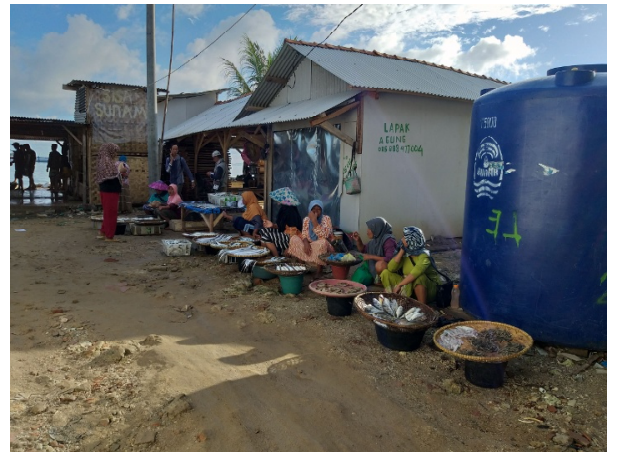

Fig. 11. Recovery of livelihoods without government assistance (community self-help)

\section{Conclusion}

Increased incidence of medium and large-scale disasters and which are difficult to predict demands good disaster resilience. The role of the social dimension is very large in building disaster resilience. Social capital on a community scale is important in the context of postdisaster recovery efforts. Disaster risk can be reduced in the future with disaster mitigation and adaptation efforts. Social networking, experience / social memory, belief systems all contribute to increasing resilience and disaster risk reduction.

This research is one of the PITTA RESEARCH at the University of Indonesia with the number NKB0633/UN2.R3.1/HKP.05.00/2019.

\section{References}

1. E. Aldrian, M. Karmini, Budiman, D. Sucahyono, I. Budiani. Pusat Perubahan Iklim dan Kualitas Udara (Indonesia), issuing body. Adaptasi dan mitigasi perubahan iklim di Indonesia. Kemayoran, Jakarta Pusat: Pusat Perubahan Iklim dan Kualitas Udara, Kedeputian Bidang Klimatologi, Badan Meteorologi, Klimatologi, dan Geofisika (2011).

2. R. D. Abrauw. Wilayah rawan longsor di Kota Jayapura. Retrieved from 10.7454/jglitrop.v1il.4 (2017).

3. Y. Arifianti, F. Agustin. GIS Landslide. Springer, Tokyo. DOI https://doi.org/10.1007/978-4-43154391-6 (2017).

4. G. Ngadisih, N. P. Samodra, Bhandary, R. Yatabe. GIS Landslide. Springer, Tokyo. DOI https://doi.org/10.1007/978-4-431-54391-6_8 (2017).

5. Badan Nasional Penanggulangan Bencana (BNPB). Data dan Informasi Bencana Indonesia, BNPB, Retrieved from < http://dibi.bnpb.go.id/> UN Office for Disaster Risk Reduction (UNISDR). Living with risk: a global review of disaster reduction initiatives (2004).

6. J. Twigg. Disaster Risk Reduction Interagency Coordination Group, (2007).

7. H. Deeming (ed.). Framing Community Disaster Resilience. First Edition. Hoboken, NJ. John Wiley and Sons, Inc (2019).

8. R. Shaw and A. Sharma (ed.). Climate and disaster resilience in cities. Bingley: Emerald Group Publishing (2011).

9. A. M. Sadri, S. V. Ukkusuri, S. Lee, R. Clawson, D. Aldrich, M. S. Nelson, J. Seipel, D. Kelly. Nat Hazards 90(3), 1377-1406. Retrieved from 10.1007/s11069-017-3103-0 (2018).

10. S. Khalili, M. Harre, P. Morley. Geoenviron Disasters 5(1). Retrieved from 10.1186/s40677018-0114-4 (2018). 
11. J. R. Simms. J Coastal Resch 332 408-420. Retrieved from 10.2112/jcoastres-d-1500193.1(2017).

12. S. Z. Janif, P. D. Nunn, P. Geraghty, W. Aalbersberg, F. R. Thomas, M. Camailakeba, Fiji. E\&S 21(2). Retrieved from 10.5751/es-08100210207 (2016).
13. O. Shalih. Adaptasi Penduduk Kampung Melayu Jakarta Terhadap Banjir Tahunan. Tesis, University of Indonesia (2012).

14. N. W. Lazarus. GeoJournal, 79(5), 635-648. Retrieved from 10.1007/s10708-014-9521-6 (2014).

15. Pemerintah Kabupaten Pandeglang. Dokumen Kajian Kebutuhan Pascabencana. Pemerintah Kabupaten Pandeglang, Pandeglang, Indonesia. hal. III1-III35 (2019). 